УДК 340

DOI 10.31.65/2520-6966-2020-13i-99-79-86

\author{
А. Дубяга \\ аспірант 2-го року навчання, \\ Донецький національний університет ім. В. Стуса (м. Вінниця). \\ ORCID 0000-0002-8143-4980
}

\title{
Роль симулякрів у гібридних конфліктах сучасності
}

У статті визначено особливості гібридної війни, висвітлено їі основні складові, на основі аналізу протистояння Росії й України виокремлено етапи цього виду протистояння. Розглянуто роль симулякрів як образів викривленої реальності для створення підгрунтя в країні, що є об'єктом агресії, насамперед створення хибних образів і формування лояльного до агресора прошарку населення. Виявлено особливості фрормування та застосування симулякрів на окремих етапах гібридної війни. На основі наведених прикладів фрейкових інфрормаційних повідомлень простежено "еволюцію" симулякру в ході гібридної військової кампанії, визначено їх вектори та вплив на свідомість населення. Проведена наукова розвідка свідчить, що створені симулякри в умовах інформаційної блокади та тотального інформаційного контролю формують видозмінену реальність у свідомості об’єктів впливу, що зумовлює активну протидію правдивій інфрормації. Це в свою чергу знаменує перемогу симулякру як компонента гібридної війни.

Ключові слова: гібридна війна, симулякр, викривлена реальність, багатополярний світ, глобалізація.

Процеси глобалізації, значний науково-технічний прогрес, особливо у сфрері озброєнь, призвели до переорієнтації конфрліктів між державами в інші сфери буття. Розуміння того, що глобальні чи континентальні збройні конфлікти можуть призвести до знищення людства, створило прецедент до розвитку таких видів війн, як торговельні, інфрормаційні та гібридні. На сьогоднішній день не можна говорити про те, що згадані вище види війни є новими, але саме у XXI столітті вони набувають нових обрисів, відбуваються процеси трансформації й об'єднання окремих видів в один. Таким видом війни $€$ гібридна війна, яка може взагалі не передбачати збройного конфрлікту, навіть локального масштабу, проте має не меншу руйнівну силу. Гібридні війни передбачають значну інформаційну атаку, у ході якої фрормується суспільна думка, створюються образи та символи, що використовуються державами-агресорами з певною 
метою. Цим зумовлюється актуальність виявлення ролі симулякрів у гібридних конфліктах початку XXI століття.

Проблематика гібридної війни як форми сучасного конфлікту активно розробляється такими дослідниками, як К. Попович [9], О. Кріслата [4], Є. Магда [6], М. Таканенко [11], С. Полумієнко [8] й ін. Розробка категорії "симулякр" переважно розглядається у фрілософський площині, зокрема такими сучасними українськими науковцями як О. Скалацька [10], О. Поліщук [7] та ін.

Мета статті полягає в розкритті значення симулякрів у веденні гібридної війни.

Виклад основного матеріалу. У наукових колах концепт "гібридна війна" розглядається в декількох напрямах, тому на сьогоднішній день існує певний плюралізм у визначенні самого поняття. К. Попович наводить таке визначення цьому виду війни: "Гібридна війна - війна, основним інструментом якої $є$ створення державоюагресором в державі, обраній для агресії, внутрішніх протиріч та конфліктів з подальшим їх використанням для досягнення політичних цілей агресії, які звичайно досягаються звичайною війною" [9, с. 75]. Це, доволі точне, визначення цього різновиду конфрлікту передбачає застосування інформації як потужного інструмента фрормування суспільної думки в країні або її частині, яка є об'єктом нападу. У будьякому разі гібридна війна застосовується у тих випадках, коли пряме військове вторгнення $є$ неможливим або небажаним. Найчастіше "небажаність" прямого військового вторгнення зумовлена геополітичними причинами та небажанням виступати агресором в очах світової спільноти. Адже під час ведення гібридної війни, на відміну від прямого військового вторгнення, участь у ній ще необхідно довести. Навіть у випадках, коли і розв'язання війни, і участь у ній $є$ очевидними (як на Сході України, де гібридна війна була розв'язана Російською Федерацією і досі триває [2]), держава агресор, заперечуючи свою причетність до конфлікту, може доволі тривалий час уникати активної протидії. Гібридні війни як засіб вирішення дипломатичних колапсів і задоволення своїх потреб стають дедалі популярнішими. Вони ввійшли в широкий вжиток за часів біполярності у світі. Саме за часів "холодної війни", уникаючи прямого зіткнення. Америка та СРСР використовували локальні конфрлікти й інформаційні кампанії для обмеження можливостей супротивника та отримання геополітичної чи економічної переваги. Зникнення соціалістичного табору у світі повинно було змінити ситуацію. Америка, як єдина світова держава, мала виконувати роль світового судді та не допускати проявів гібридних війн. Але, як зазначають окремі дослідники, 
доба PaxAmericana добігає кінця і на зміну однополюсному світу приходить багатополюсний [5]. Ураховуючи цей аспект, можна припускати, що гібридні війни у майбутньому виникатимуть ще частіше та їх технології розвиватимуться у геометричній прогресії.

Ключовим фактором успіху в гібридній війні $є$ потужна інформаційна компанія, яка повинна створити внутрішні протиріччя, суспільний конфлікт і лояльно налаштувати частину населення. Вочевидь, ці прийоми гібридної війни не нові, але саме зараз відбуваються зміни балансу між інформаційними кампаніями та використанням зброї на користь інформації [6]. Саме в цьому аспекті головну роль виконують симулякри. У фрілософському дискурсі існує багато визначень і підходів до розуміння цього феномену. У розрізі проблематики, що розглядається, симулякр розуміється в такому тлумаченні: "Симулякр - імітація і заміна реального, одиниця підробленого сенсу, іррефрерентний знак" [7]. Інколи симулякр називають копією копії, яка поступово перестає відповідати оригіналу. Іншими словами, симулякр - це викривлена копія реальності, яка собою заміщує останню. У цьому контексті доцільно запропонувати та розглянути головні етапи розгортання гібридної війни у площині використання симулякрів (таблиця 1).

\section{Етапи гібридної війни}

Таблиця 1

\begin{tabular}{|l|l|}
\hline \multicolumn{1}{|c|}{ Етап } & \multicolumn{1}{|c|}{ Характеристика } \\
\hline I. Підготовчий & $\begin{array}{l}\text { Створення внутрішніх протиріч і соціальної напруги в } \\
\text { країні, культивація образу "друга" серед населення, } \\
\text { досягнення лояльності }\end{array}$ \\
\hline II. Перехідний & $\begin{array}{l}\text { Використання формального приводу, що веде до актив- } \\
\text { ного втручання в інформаційне поле країни, використан- } \\
\text { ня фейкових новин, залякування лояльної частини } \\
\text { населення "жахливими перспективами" }\end{array}$ \\
\hline ІІІ. Активної & $\begin{array}{l}\text { Формування та закріплення образу ворога, заволодіння } \\
\text { тотальним контролем над інформаційним простором. } \\
\text { Реалізація інших компонентів гібридної війни (фор- } \\
\text { мування незаконних збройних фрормувань, терорис- } \\
\text { тичних угруповань, захоплення територій тощо) }\end{array}$ \\
\hline IV. Підтримки & $\begin{array}{l}\text { Систематична робота з населенням, постійне створення } \\
\text { нових негативних образів "ворога", культивація фрейко- } \\
\text { вихальтернативних сценаріїв }\end{array}$ \\
\hline
\end{tabular}

Розглянемо роль створених симулякрів у розгортанні агресії на Сході України. Створені Росією симулякри історії та сучасності дозволили створити підґрунтя для розгортання агресії на Сході України в 
2014 році. Проте буде помилкою вважати 2014 - роком початку гібридної війни проти України, адже формування суспільної думки та викривлення історичної пам'яті частки населення на свою користь неможливе за короткий проміжок часу. Цей процес дуже тривалий, i тому можна припускати, що "вибух" 2014 року став результатом підготовки десятиліть. Головний симулякр, який використовується Росією на всьому пострадянському просторі, - "ідея єдності (братерства) народів на чолі зі старшим братом (Росією)". Цей елемент формується завдяки насадженню викривленої історичної пам'яті симулякру справжньої історичної пам'яті. Саме історична пам'ять $€$ первинним плацдармом для початку агресії [3, с. 254]. Тривалий час саме в переважно російськомовних регіонах України дуже потужно культивувався цей міф. Ідея братерства постійно мусувалась за допомогою засобів масової інформації, кіно, створювались громадські організації відверто проросійської орієнтації. 3 цього приводу Ю. Теміров зазначає, що політика пам'яті виступає основним інструментом як для консолідації суспільства всередині країни, так і реалізації стратегічних ініціатив у зовнішній політиці, а саме здобуття статусу світової держави [12, с. 265]. Більше того, виведення мовного аспекту на перший план дозволило піти набагато далі та затвердити у багатьох громадян фрормулу: "мова спілкування = національність". Виходячи з цього, значна частка населення Південно-Східного регіону України почала себе ідентифікувати як етнічних росіян. Це і $\epsilon$ головний базис для початку другої фази гібридної війни, коли населення не тільки не чинило супротиву незаконним збройним формуванням і російським військовим, а навпаки, допомагала, вбачаючи в них своєрідних "визволителів".

Перехід від багаторічної тривалої підготовки до активних дій стався у 2014, коли як привід була використана Революція Гідності [1] й у східних регіонах почав активно використовуватись нашвидкуруч створений симулякр у вигляді "бандерівців", які масово їдуть на Схід вбивати російськомовне населення. Саме навесні 2014 року, спираючись на проросійські громадські організації шляхом закидання диверсійних груп, постачання зброї та захоплення об'єктів управління, почалась активна фраза гібридної війни. Як видно, далеко не другорядну роль також відіграв симулякр.

Активна фраза конфлікту, що розглядається поряд з інформаційними атаками, має і збройний компонент. Військове протистояння $€$ дуже якісним ґрунтом для створення все нових симулякрів, що замінюють реальність і фрормують стійку суспільну думку. Негативний образ українських військових активно формується за допомогою 
засобів масової інформації, демонструючи фейкові інформаційні повідомлення про злочини проти людства та відверті звірства. Яскравими прикладами є інформаційні повідомлення про розіп'ятого хлопчика у звільненому Слов'янську, обстріл збройними силами України Маріуполя та тролейбуса в Донецьку [13]. Для збільшення ефекту залякування також використовувались симулякри, які фрормувались протягом тривалого часу підготовчого етапу, а саме жах перед всесвітньою змовою проти Росії (про те, що частка населення почала себе вважати саме росіянами, ми вже згадували вище) з боку Америки. Тому інформаційні вкидання про постачання з боку США озброєнь для розпалювання війни сприймали взагалі безапеляційно. Звичайно, симулякри активної фрази гібридного конфлікту повинні створюватись дуже швидко, тому для посилення їхньої ефрективності часто доводиться спиратись на вже сформовані ірреальні образи. Також реалізація сценарію формування суспільної думки в ході активної фрази гібридного протистояння можлива лише за умов інформаційної блокади та тотального контролю над інформаційним простором, що було досягнуто дуже швидкими темпами. 3 плином часу симулякри повністю замінили собою реальність у свідомості людей на тимчасово окупованих територіях Сходу України. Нова інформація сприймається крізь призму штучно створеної історії та колективної пам'яті, а правдива інформація та намагання спростувати "міфрологічну" свідомість викликає когнітивний дисонанс і повністю заперечується. Виходячи з цього, можна припускати, що відновлення контролю Україною над інфрормаційним простором окремих районів Донецької та Луганської областей уже не буде мати успіху та зможе вплинути на незначну частку населення.

Фаза підтримки конфрлікту $є$ дуже тривалою та виснажливою. Створені маріонеточні анклави на Сході України використовуються агресором як предмет шантажу. Для підтримки лояльності населення й образу ворога починають створюватись альтернативні сценарії сучасності. Головним посилом $є$ слово "якщо б". Якщо б Україна "не напала на власний народ...", "не зруйнувала підприємства...", "не запровадила блокади..." Іншими словами, малюється образ винуватця всіх бід регіону та створюються франтастичні образи яскравого і заможного життя, до якого їх, безперечно, може привести тільки Росія.

Підбиваючи підсумки, можна наголосити, що заміна реальності симулякрами у свідомості людей, створення міфічних образів історичної та колективної пам'яті, навіювання образів ворога за допомогою фрейкової інформації $є$ невід'ємним і одним з головних інструментів гібридної війни. Симулякр як ключовий чинник фрормування викривленої реальності виступає провідним аспектом сучасної гібридної 
війни. Намагання Росії отримати статус світової держави та повернути концепт біполярного світу може розглядатись як розпалювання Другої холодної війни. Локальні гібридні конфлікти в Грузії й Україні $\epsilon$ спробами перевірити реакцію світової спільноти та закріпити свій вплив на пострадянському просторі. Тому можна передбачити, що подібні гібридні конфлікти, особливо на пострадянському просторі, будуть виникати і надалі. На сьогоднішній день украй важливо бути готовим до такого роду війни. I якщо передвісником "класичної війни" $€$ нарощування кількості озброєнь та концентрація військ біля кордонів, то у випадку підготовки гібридної війни особлива роль повинна відводитись аналізу інформаційного простору та культивації симулякрів.

\section{Література}

1. 10 фактів про збройну агресію Росії проти України. URL: https://mfa. gov.ua/10-faktiv-pro-zbrojnu-agresiyu-rosiyi-proti-ukrayini (дата звернення: 19.03.2020).

2. Горбулін В. Гібридна війна: все тільки починається. Дзеркало тижня. 2016. URL: http://gazeta.dt.ua/internal/gibridna-viyna-vse-tilki-pochinayetsya-_.html. (дата звернення: 19.03.2020).

3. Дубяга А. Історична пам'ять як ключовий чинник гібридної війни в Україні. Історичні і політологічні дослідження. Спеціальний випуск: доповіді на Міжнародній науково-практичній конференції "Трансформації історичної пам'яті". Вінниця, 2018. С. 252-256.

4. Кріслата О. Гібридна війна та її інформаційна складова. URL: http://www.Isl.lviv.ua/wp-content/uploads/Zb/NDI2018/PDF/14.pdf (дата звернення: 19.03.2020).

5. Лексина Е. А. США: конец эры РахAmericana или подготовка к резкому броску? [USA: the end of the RaxAmericana era or preparation for a sharp throw?]. URL: https://cyberleninka.ru/article/n/ssha-konets-ery-pax-americana-ilipodgotovka-k-rezkomu-brosku (дата звернення: 19.03.2020).

6. Магда Є. Виклики гібридної війни: інформаційний вимір. URL: http://www.irbisnbuv.gov.ua/cgibin/irbis_nbuv/cgiirbis_64.exe?C21COM=2\&l21 DBN $=U J R N \& P 21 D B N=U J R N \& I M A G E \_F I L E \_D O W N L O A D=1 \& I m a g e$ file_name $=P$ DF/Nzizvru_2014_5_29.pdf (дата звернення: 19.03.2020).

7. Поліщук О. Симулякризація як один з головних принципів сюжетотворення альтернативно-історичних сценаріїв. Актуальні питання гуманітарних наук. 2015. № 11. С. 194-200.

8. Полумієнко С. К. Гібридна війна, її окремі передумови, стратегії та наслідки. Вісник НАН України. 2017. № 8. С. 72-82.

9. Попович К. В. Гібридна війна як сучасний спосіб ведення війни: історичний та сучасний виміри. Науковий вісник Ужгородського університету. Серія "Історія". 2016. Вип. 2 (35). С. 75-78.

10. Скалацька О. В. Концепт "симулякр" у фрілософському дискурсі Ж. Бодрійяра. URL: http://journals.uran.ua/index.php/2312-1947/article/view/ 29170 (дата звернення: 19.03.2020). 
11. Тараненко М. М. Гібридна війна в Україні: історія та сучасність. Вісник НТУУ "КПІ". Політологія. Соціологія. Право. 2016. Вип. 3/4 (31-32). C. $190-200$.

12. Теміров Ю. Фактор "історичної пам'яті" у зовнішній політиці сучасної Росії. Історичні і політологічні дослідження. Спеціальний випуск: доповіді на Міжнародній науково-практичній конференції "Трансформації історичної пам'яті". Вінниця, 2018. С. 257-266.

13. Топ 20 фейків російських медіа (3MI). URL: http://mip.gov. ua/files/broshury/top_20_feikiv_ros_media.pdf (дата звернення: 19.03.2020).

\section{References}

1. 10 faktiv pro zbroinuahresiiuRosiiprotyUkrainy. URL: https://mfa.gov.ua/10 faktiv-pro-zbrojnu-agresiyu-rosiyi-proti-ukrayini.(data zvernennia 19.03.2020). [in Ukrainian].

2. Horbulin, V. (2016) Hibrydna viina: vse tilky pochynaietsia [Hybrid war: it's just beginning] URL: Dzerkalotyzhnia. http://gazeta. dt. ua/internal/gibridnaviyna-vse-tilki-pochinayetsya-_. html. -(data zvernennia 19.03.2020). Nazva z ekrana. [in Ukrainian].

3. Dubiaha, A. (2018). Istorychna pamiat yak kliuchovyi chynnyk hibrydnoi viiny $v$ Ukraini [Historical memory as a key factor in the hybrid war in Ukraine]. Istorychni i politolohich nidoslidzhennia. Spetsialnyi vypusk: dopovidi na mizhnarodni i naukovo-praktychnii konferentsii "Transformatsi iistorychnoi pamiati". Vinnytsia. S. 252-256.

4. Krislata, O. Hibrydna viina ta ii informatsiina skladova [Hybrid war and its information component]. URL: http://www.Isl.Iviv.ua/wp-content/ uploads/Zb/NDI 2018/PDF/14. pdf. (data zvernennia 19.03.2020).

5. Leksyna, E. A. SShA: konetseriPax Americana ilypodhotovka k rezkomubrosku? URL: https://cyberleninka.ru/article/n/ssha-konets-ery-paxamericana-ili-podgotovka-k-rezkomu-brosku. (data zvernennia 19.03.2020). [in Ukrainian].

6. Mahda Ye. Vyklykyhibrydnoiviny: informatsii nyivymir [Challenges of hybrid warfare: information dimension] URL: http://www.irbisnbuv.gov.ua/cgibin/ irbis nbuv/cgiirbis_64.exe?C21COM=2\&l21DBN=UJRN\&P21DBN=UJRN\&IMAGE_FILE_ DOWNLOAD=1\&Image_file_name=PDF/Nzizvru_2014_5_29. pdf. (data zvernennia 19.03.2020) [in Ükrainian].

7. Polishchuk, O. (2015). Symuliak ryzatsiia yak odyn z holovnykh pryntsypiv siuzhetotvorennia alternatyvno-istorychnykh stsenariiv [Simularization as one of the main principles of plot-creation of alternative-historical scenarios]. Current issues of humanities - Aktualni pytannia humanitarnyk hnauk. 11. 194-200. [in Ukrainian].

8. Polumiienko, S. K. (2017). Hibrydnaviina, yiiokremiperedumovy, stratehii ta naslidky [Hybrid war, its individual preconditions, strategies and consequences] Visnyk NAN Ukrainy - Bulletin of the NAS of Ukraine 8. 72-82. [in Ukrainian].

9. Popovych, K. V. (2016). Hibrydnaviina yak suchasnyi sposib vedennia viiny: istorychnyi ta suchasnyi vymiry [Hybrid warfare as a modern way of waging war: historical and modern dimensions]. Naukovyi visnyk Uzhhorodskoho 
universytetu, seriia "Istoriia" - Scientific Bulletin of Uzhhorod University, Series "History". 2 (35). 75-78.

10. Skalatska, O. V. Kontsept "symuliakr" u filosofskomu dyskursi Zh. Bodriiiara URL: (data zvernennia 19.03.2020). [in Ukrainian].

11. Taranenko, M. M. Hibrydnaviina v Ukraini: istoriia ta suchasnist. Visnyk NTUU "KPI". [Hybrid war in Ukraine: history and modernity. Bulletin of NTUU "KPI". Politolohiia. Sotsiolohiia. Pravo. - Politology. Sociology. Right. 3/4 (31-32) 190-200.

12. Temirov, Yu. 2018. Faktor "istorychnoi pamiati" u zovnishni i politytsi suchasnoi Rosii [Factor of "historical memory" in the foreign policy of modern Russia. Historical and political science research] Istorychni i politolohi chni doslidzhennia - Historical and political science research. Special issue: reports at the international scientific-practical conference "Transformations of historical memory" Vinnytsi, 257-266. [in Ukrainian].

13. Top 20 feikivrosiiskykh media (ZMI) URL: Rezhymdostupu:http://mip. gov.ua/files/broshury/top_20_feikiv_ros_media. pdf. (data zvernennia 19.03. 2020). [in Ukrainian].

\section{A. P. Dubyaga}

Graduate student of Vasyl Stus Donetsk National University (Vinnytsia)

\section{The role of simular bloods in modern hybrid conflicts}

The article defines the features of a hybrid war, highlights its main components, based on the analysis of the confrontation between Russia and Ukraine, the stages of this type of confrontation are highlighted. The role of simulacra as an image of distorted reality for creating the foundation in the country, which is the object of aggression, primarily the creation of false images and the formation of a layer of society loyal to the aggressor, is considered. The features of the formation and use of simulacra at certain stages of the hybrid war are revealed. Based on the given examples of fake informational messages, the "evolution" of the simulacrum was traced during the hybrid military campaign, their vectors and their influence on the consciousness of the population were determined. The conducted scientific intelligence indicates that the simulacra created under the conditions of information blockade and total information control form a modified reality in the consciousness of objects of influence, which leads to active opposition to truthful information. This, in turn, marks the victory of simulacra as a component of hybrid war.

Key words: hybrid warfare, simulacrum, distorted reality, multipolar world, globalization. 